\title{
THE SYMBOLIC CONVERGENCE WITHIN THE TRANSFORMATION OF CITY OF BEKASI FROM THE MOST INTOLERANT CITY INTO THE MOST TOLERANT CITY
}

\author{
VANIA UTAMIE SUBIAKTO ${ }^{1}$ \\ Communication Studies Study Program, Mercu Buana University, Mercu Buana University \\ Kampus, Meruya Selatan Street No. 1, Kembangan, West Jakarta 11650
}

\section{SAEFUDIN ZUHRI ${ }^{2}$}

Public Administration Study Program, Krisnadwipayana University,Krisnadwipayana University Campus, Unkris Street, Jatiwaringin, Pondok Gede, Bekasi, 17411

\section{GUNAWAN, M.IKOM ${ }^{3}$ \\ Communication Studies Study Program, Mercu Buana University,Mercu Buana University Kampus, Meruya Selatan Street No. 1, Kembangan, West Jakarta 11650}

\begin{abstract}
Out of 94 Cities that become the object of assessment within the Index of Tolerant City by Setara Institute, the City of Bekasi is the only city that has undergone the transformation from the second most intolerant city in 2015 into the sixth most tolerant city in 2018. Departing from the statement, through this article the researchers would like to explain the transformation within the ranking of the index. By using the theory of symbolic convergence, the results of the study show that such transformation has been the result of the action taken by the City of Bekasi Government. The stigma of being the most intolerant city has been stripped off by the City of Bekasi Government through a number of political programs and policies such as the deprivation of the discriminative policies, the provision of construction permit for several churches that used to be refuted by several mass organizations, and continuous campaigns of diversity (kebhinekaan). The reason is that the City of Bekasi Government has been impacted by the stigma of being the most intolerant city and this situation has urged the Government to turn tolerance into the most important issue within the City of Bekasi nowadays.
\end{abstract}

Keyword: Symbolic Convergence, Tolerance, and Social Transformation

\subsection{INTRODUCTION}

The transformation that the City of Bekasi has undergone from the intolerant city into the tolerant city has harnessed a big question and drawn the interest to be scientifically reviewed. Returning to the Post-Reformation Era, the inter-religion and inter-ethnic conflicts have taken place in numerous areas. In addition, the trend of intensity on such conflict has been on the rise with a number of fluctuating transformations. It is already well-noted that the conflict of ethnic, religion, race, and group in Ambon (1999), Poso (2000-2001), and Sampit (20002001) has not only been a local incident but has also been the trigger for the appearance of

\footnotetext{
${ }^{1}$ The author is a lecturer in the Communication Studies Study Program, Faculty of Communication Studies, Mercu Buana University.

${ }^{2}$ The author is a lecturer in the Public Administration Study Program, Faculty of Administration Studies, Krisnadwipayana University.

3 The author is a lecturer in the Communication Studies Study Program, Faculty of Communication Studies, Mercu Buana University.
} 
violently extreme groups that commit terrors on the behalf of religion. These groups have been the mastermind behind a number of bombings, shootings, and stabbings on the behalf of religion even until today (Zuhri, 2017, p.7). The presence of violent extremism was marked by the inability to embrace the presence of others, which leads to refutation and even resistance.

The case of religious intolerance can be categorized into several types of violations namely: (1) violation by the state due to the desire to control the religious expression; (2) violation due to the intolerant acts by both the state actors and the non-state actors; (3) violation due to the failure of the state in overcoming both social discrimination and social violation upon certain religious entities; and (4) violation due to the implementation of certain policies that harm minor religions (Asep, 2016). In addition, the intolerance cases such as attacks and dismissals of discussions, destruction of burial sites, attacks on the prayer of rosary, intimidation toward certain groups such as Syiah and LGBT, cessation of church service, and closure of prayer house often take place in the cities of culture throughout Indonesia.

The incidents on the violation toward the freedom of embracing certain religions that take place in the City of Bekasi and also in other cities throughout Indonesia often linger around the problems of refuting the service or the presence of Christian prayer houses, both the ones that have been completely constructed and the ones that have still been under construction. In addition, the protracted process in combination with the less active role displayed by the government of a city has given rise on the number of the intolerant acts in the present time. Most of the times the government in a city takes action after the community members take the initiative to do resistance or to deal with the case of intolerance directly. With regards to the situation, the issues of Christianisation, apostasy, and resistance by Moslem people become a peculiar pattern in the case of freedom in embracing religion and faith currently. Therefore, looking at the high number of intolerant cases in Indonesia, it can be concluded that the Indonesian society has still displayed minimum initiative in establishing harmony and tolerance among the religious entities.

The presence of social reality toward the increasing trend of intolerance cases throughout Indonesia within the Post-Reformation Era has encouraged the researchers to conduct a study with the focus on the City of Bekasi, which used to be known as one of the most intolerant cities. It is apparent from the Index of Tolerant City in 2012 which has placed the City of Bekasi into the second most intolerant city. The same result is also found in the Index of Tolerant City on 2015, which has placed the City of Bekasi one rank higher than the City of Bogor with the lowest index score of tolerance (Report Summary, Indeks Kota Toleran 2015, SETARA Institute, November 16th, 2015). In terms of variables, the City of Bekasi has been put into the group of intolerant city because of the government regulation (the discriminative Regional Mid-Term Development Plan and Regional Regulation), the government action (the statement and the response of the Government on the freedom of embracing religion/faith), and the religious demography (the composition of the population based on the religion).

The portrait of intolerance within the City of Bekasi has been recorded in the results of a research by Wahid Institute on 2011. Rachmand Effendi, the Mayor of Bekasi, once used to issue a prohibition on the activities of Ahmadiyah through the Regulation of the City of Bekasi Mayor Number 40 of 2011 dated October 13th, 2011. In addition, the City of Bekasi used to ban the congregation of Indonesian Christian Church Taman Yasmin (GKI Taman Yasmin) to hold their ministry on the sidewalks; in fact, the ministry by this Christian church once was dismissed by the Civil-Service Police Unit in 2011. In another occasion, Front of Anti-Apostasy Bekasi (FAPB, Front Anti-Pemurtadan Bekasi) used to ban the activities of Galilea Church (Gereja Galilea) in South Bekasi. Not to mention, Albi (Alliance of Islam in Bekasi or Aliansi Islam Bekasi), Forum of Moslem Communication in Indonesia (Forkami, Forum Komunikasi Muslim Indonesia), and Front of Islamic Defender (FPI, Front Pembela 
Islam) used to raid some churches and also ban their activities. Last but not the least, Indonesian Council of Ulama (MUI, Majelis Ulama Indonesia) for the City of Bekasi even used to ban the activities of Friday prayers for the Ahmadiyah congregation in the Al-Misbah Mosque Bekasi (The Wahid Institute, 2011).

The situation became worse due to the issuance of the Regulation of City of Bekasi Mayor Number 68 of 2013 on the Implementation of Local Content Curriculum for History and Culture in Bekasi toward Elementary School Degree and Junior High School Degree. This regulation has been discriminative because some of the materials or the contents within the regulation tend to expose the major religion more instead of accommodating the potential diversity within religions and faiths (Erdianto, 2017).

The portrait of the positive progress made by the City of Bekasi cannot be set apart from the communication strategy that the Mayor of the City of Bekasi has pursued in adjusting the state policy into the public policy. Several months ago, Mayor Rahmat, the Mayor of Bekasi, should deal with the huge wave of mass from the intolerant groups who went against his decision. This mass of intolerant groups demanded that Mayor Rahmat should deprive the permit of Santa Clara Church, whereas he displayed a very strong message of tolerance that he shall not deprive the permit of Santa Clara Church only because of being demonstrated or being intimidated by a group of people or mass (Setara, 2017). In 2018 the City of Bekasi has been at the Top 10 Tolerant City in Indonesia by occupying the sixth place after Singkawang, Salatiga, Pematang Siantar, Manado, and Ambon.

Based on a number of observations, the researchers found the presence of the interaction between the state officials, such as the Mayor of Bekasi, and the public within quite a long period of time. In 2012, the results of the index show that the City of Bekasi has been in the second place of most intolerant city. Similar finding is also shown by the Index of Tolerant City 2015, which has put the City of Bekasi one rank higher than the City of Bogor under the two bottom-ranks (Setara, 2015). The process that the City of Bekasi has undergone is known as symbolic convergence. According to Bormann, symbolic convergence is a general theory that analyses the phenomena of message trade off that gives rise to the group awareness with implication on the presence of shared meaning, motif, and feeling (Hirokawa \& Pole, 1986, p.12; Suryadi, 2010, p.430). Bormann (1990, p.106; Suryadi, 2010, p.431) defines that convergence is a way in which the symbolic world of two individuals or more meet each other, get closer to each other, and eventually intersect with each other. On the contrary, the term symbolic itself is related to the tendence of human beings to interpret and internalize meaning on numerous symbols, signs, events, and even actions (Bormann, 1986, p.221; Suryadi, 2010, p.431).

In the practice, there are individuals who develop their own personal symbolic words in order to complete each other so that they have the basis for creating communities, for discussing shared experiences, and for creating shared understandings (William, Benoit L., et al, 2001, pp.380-381; Arianto, 2012, p.3). It is this phenomenon of construction that takes place in the communication within the City of Bekasi. As a result, the City of Bekasi has undergone the transformation from the most intolerant city into the most tolerant city. Not to mention, due to the fact that the society within the City of Bekasi has been more and more heterogenous, the City of Bekasi Government has appealed that the act of being tolerant to any religion followers should be prioritized.

Quoting Lippman (2007), image refers to the description of reality and, therefore, image should not always be in line with reality. Image is indeed the view of the world in accordance with the perception of an individual. Lippman regards it as "the picture in our head." Then, image itself is formed by the information that has been retrieved. With regards to the statement, the reality that has been portrayed by the media is the reality that has been selected 
or the second-hand reality. Eventually, society forms their own image of individual or social environment based on the reality that has been elaborated by the mass media (Lestaryasca, 2013, p.51). The presence of the image that has been formed triggers the presence of the shared understanding within the group and the shared understanding, thus, is able to improve the social awareness and maintain the communal cohesion. Therefore, in order to deal with the intolerance that has caused the disintegration among the religious people, a society should have a strong sense of tolerance. As a result, the society should embrace the different race, ethnicity, and faith in accordance with the individuals.

Vania (2019, p.12) states that since constructed reality shapes mass opinion then people tend to be priori and cynical toward the mass opinion. The position of "Social Construction of Mass Media" is a substance correcting weaknesses and complement "Social Construction of Reality"; therefore, it puts excess on mass media and media effect. As a consequence, people tend to be more creative and imaginative in dramatizing the story of an event, an action, a story, and event a symbol during the interaction between one another. Such capacity has made the interaction within the society to be occupied with the efforts of dramatizing the interesting message. Therefore, the solidity within the society should be maintained through inter-society members interaction and inter-community members interaction within the City of Bekasi.

The interesting transformation from the most intolerant city into the most tolerant city that the City of Bekasi has undergone can be traced back from the Index of Tolerant City 2017 and the Index of Tolerant City 2018 that have been released by SETARA Institute. In the two indexes, the City of Bekasi has shown significant progress. The City of Bekasi has leaped from the rank 93rd (two bottom-ranks) in 2015 into the rank 53rd by 2017. Thus, it can be identified that the City of Bekasi has leaped from Cluster 4 into Cluster 3. Such significant progress is mainly supported by the increasingly positive standing position, statement, and action made by the Mayor of Bekasi, Rahmat Effendi, in responding to the events of intolerance. In this regard, the researchers view that the City of Bekasi has the following attributes within the indexing of the Tolerant City:

1. The City of Bekasi has conducive regulations for the practice and the promotion of tolerance, both in terms of planning and in terms of implementation within the regulation.

2. The statement and the action by the apparatus of the City of Bekasi have been conducive for the practice and the promotion of tolerance.

3. A number of events and actions toward the violation within the freedom of embracing religion and faith have been low or non.

4. The City of Bekasi Government has shown sufficient efforts in administrating the diversity within the religious identity of the society (Setara, 2018).

Looking back at the situation, the present study is important to conduct in order to confirm the progress on the score of tolerance index amidst the facts that the trend of intolerance has been on the rise in the Capitol and the surrounding cities during the Presidential Election 2014, the Jakarta Gubernatorial Election 2017, and Presidential Election 2019. Various actions on the behalf of religions and various elements of religions have been resisted by various actions of diversity, causing the society in Jakarta dichotomized. Many articles and news reports strengthen that the dichotomized society resulted from such political phenomena will extend throughout the regions in Indonesia (Burhani, 2017, p.56). After the case of blasphemy that come along with the dynamics of Jakarta Gubernatorial Election 2017, the issues that preserve the dichotomized conditions of the society has also been found in the Presidential Election 2019. 
According to Cooley (1902), in his concept of Looking Glass Self, there are three main elements that influence the perspective, the attitude, and the action of an individual namely: (1) imagination about how an individual perform before the other people; (2) imagination about how other people evaluate him or her; and (3) emotional response toward the evaluation made by other people. With regards to the statement, people become intolerant because they perceive fear, threat, and danger signal within himself if they let the party under resistance to flourish or stay exist. Therefore, the attitude of these people is unacceptability toward the different others because the different others have been considered as a threat or have no equal characteristics with these people. Such description is the complete reversal of the meaning on tolerance according to Walzer (in Sutanto, 2007). Then, the imagination of tolerance and intolerance can be spread by one party to another through the inter-actor symbolic convergence. According to Robert Bales, this imagination is known as Fantasy Theme. Fantasy Theme takes place when there is a trade of imagination from a group of small scale into a group of wider scale (society). Bales regards this phenomenon as the phenomenon of convergence.

With regards to Fantasy Theme, there are several terms that should be understood in order to comprehend the symbolic convergence well. The first term is the Fantasy Theme itself. Bormann defines Fantasy Theme as the content of the message that has been dramatized in order to create the chain of fantasy. Then, the second term is Fantasy Chain. The fantasy chain is established when the message that has been dramatized by the members of a group successfully gains the response from the members of another group so that the intensity and the desire of the participants in numerous fantasies have increased. The fantasy chain that has been established will create the symbolic convergence and the foundation for the common meaning integration.

Next, the third term is Fantasy Type. According to Bormann, Fantasy Type refers to the recurrent themes of fantasy that has been discussed on different situations with different characters and backgrounds but the plot is still the same. In other words, if the plot of the narrative is still the same but the characters, the characteristics, and the settings are different, then the whole framework can be categorized into the same type of fantasy. Afterward, the fourth term is Rhetorical Visions. The fantasy themes that have developed outside the context of the preliminary developing group will develop into a rhetorical vision. Thus, the development of such fantasy will be the fantasy of the wide society and shape the rhetorical community. In every analysis of wider fantasy or wider rhetorical vision, there are always four elements namely: (1) dramatic personae or character that has been involved; (2) plot line; (3) scene; and (4) sanctioning agents (Suryadi, 2010, pp.432-435).

Ine an article entitled "Symbolic Convergence Theory: A Communication Formulation" (1985), Bormann mentions that there are three main aspects that shape the SCT theory namely: (1) the identification and the arrangement of the recurrent communication shape and pattern that indicates the appearance of shared awareness within a group under an evolutionary manner; (2) the description on the dynamic tendency within the communication system that explains why the group awareness has appeared to the surface, has continued, has declined, and has eventually disappeared; and (3) the factors that explain why the given people are involved into the act of sharing fantasy. In addition to the three main aspects, Borman also mentions two main assumptions that underlie the theory of SCT. First, reality is constructed through communication. In this regard, communication is able to construct reality through the link within the words that have been used to share the life experience or the internalized knowledge. Second, individual meaning toward symbols can experience convergence so that the meaning can turn into shared reality. According to this theory, reality is considered as the arrangement of a narrative that explains how something should be trusted by the people that have been involved. 
At the beginning, the narrative is discussed within a group and then the narrative is disseminated to the wider groups or the society. Bormann (1986, in Suryadi, 2010) also mentions six epistemological assumptions of the SCT theory namely: (1) meaning, emotion, and motif of action lie in the content of the message that has been clearly stated; (2) reality is constructed symbolically; (3) chain of fantasy creates symbolic convergence in a dramatic form; (4) analysis of fantasy theme is the main method in capturing the symbolic reality; (5) fantasy theme may appear in numerous discourses that have been developed; and (6) there are three master analogue visions namely righteous, social, and pragmatic (Suryadi, 2010, pp.431-432).

\subsection{METHOD}

In the study, the researchers implemented the qualitative approach. Specifically, the qualitative approach that had been selected was the case study. The case study itself departed from the data that had been attained. Then, the data that had been attained were analysed in order to arrive at the conclusion of the study. Creswell (2013) explains that the focus of a case study is the focus of the event that an individual, an organization, or a group has altogether with the portrait of the social life within the society. In line with the statement, according to Stake (1995) case study aims at identifying an object in-depth in order to gather complete information by using a number of data gathering procedures based on the timeline that has been set. In this context, the data within the study were gathered from the results of a study by SETARA Institute toward the City of Bekasi Government from 2015 until 2018.

In addition, within the data gathering procedures, the data gathering technique that had been implemented were observation, documentation, and in-depth interview with the primary sources. At the same time, the researchers also gathered additional data and information from the secondary sources such as journals, printed newspapers, electronic newspapers, and also field records that consisted of informal interviews, courses, seminars, expert meetings, television programs, and social media. Last but not the least, the main informant within the in-depth interview was the Director of Research SETARA Institute, the researchers of SETARA Institute who had been assigned in the City of Bekasi, and the relevant officials in the City of Bekasi Government.

\subsection{RESULTS AND DISCUSSIONS}

\section{The Construction of Tolerance and Social Dynamic within the Society in the City of Bekasi}

The City of Bekasi is a buffer for the state capitol and the society in this City of Bekasi has diverse backgrounds. The diversity within this city has long been in existence since a long time ago since it is apparent from the division of the culture area. The area which used to be one of the districts in the Regency of Bekasi has three domain ethnicities namely Sunda, Betawi, and Banten-Java. The cultural characteristics of Sunda itself lie in the farming system, while the cultural characteristics of Betawi and Banten-Java lie in the coastal culture. Despite being a very heterogenous metropolitan area, Betawi has been the dominant ethnic in the City of Bekasi (Rosyadi et al., 2010, pp.28-29).

The diversity in the City of Bekasi is apparent from the aspects of economy, especially in the sectors of trading, which has been dominated by ethics of China, Padang, Bali, Batak, and Ambon. Most of these ethnics indeed live in the City of Bekasi (Tiderman, 1983, pp.84-85; Suparman, 1985, p.193). Based on the Memoir van Overgave (Report of Position Handover) by the Resident of Batavia L.G.C.A Van Der Hoek, the population data in 1927 for the area that has been known as the City of Bekasi nowadays show the heterogenous composition within the popilation. From 126,000 people in this area, there have been 30 European people, 
7,500 Foreign Eastern people, and 155,470 indigenous people (Sopandi, 2009, p.174). The Mayor of Bekasi, Dr. Rahmat Effendi, in the media Bekasi.go.id (2018) states that the presence of the diversity within the heterogenous society of Bekasi always deliver peace, harmony, and tolerance keeping among the religious people.

The diverse population composition, both in terms of ethnics and in terms of religion, defines the description on the life of solidarity in several regions that have become the parts of the City of Bekasi. The process of cultural and religious assimilation and acculturation has been established in several regions. One of the examples for such situation can be found in Kampung Sawah, the City of Bekasi. Adon Nasrullah Jamaludin (2013) has proposed the phenomenon of harmonious relationship in Kampung Sawah. In this area, the kinship system by means of clan is not only possessed by the people from the ethnicities of Batak, Minahasa, Ambon and alike; instead, the people from the ethnicities of Sunda and Betawi also develop their own kinship system of clan, whereas the culture of Sunda and Betawi does not acknowledge such kinship system. This phenomenon is similar to the one that has been found in Kampung Jawa in Tondano (North Sulawesi) (Kinayanti Djojosuroto, 2011). Such kinship system has been established since the era of Dutch colonialization when Christianism started to spread around the region. Such process of cultural construction does not stop at the establishment of clan. In addition to it, the marriage that involves different religions has started to naturally take place as well. Consequently, just like in the Kampung Jawa in Tondano, the people in Kampung Sawah are also found to have different religions despite the fact that they belong to the same clan (Jamaludin, 2013).

The development over this region is more rapid in comparison to the City of Bekasi because the location of Kampung Sawah is in close borders with the Province of Jakarta Special Capitol. Urbanization has caused the economic wheel in this region to develop faster since the sectors of trade and industry have been dominant. At the same time, the arrival of the people from all over the regions throughout Indonesia give a peculiar colour to the society within the region. Such development has brough to the official decree that the region should expand into the City of Bekasi in 1982. Consequently, a heterogenous area has been formed due to the urbanization, which has taken place along the colonial highway system and this has been the peculiar characteristic for the City of Bekasi.

The diversity within the City of Bekasi has grown and developed along with a number of social problems that have appeared to the surface. The first social problem is the social conflict that has been on the rise due to the demographic transformation of the urban society, resulting into the economic gap. Indeed, the population growth in the City of Bekasi has been rapid along with the progress of the Province of Jakarta Special Capitol. If the City of Bekasi is mapped, there will be four areas of typology that have peculiar characteristics namely: (1) village; (2) housing; (3) trading and business centre; and (4) the combination of village, housing, and also trading and business centre (Sopandi, 2006, pp.64-65). All of the four areas have intense dynamic within the complex life of religious people.

The ethnical diversity within these areas have influenced the transformation on the population distribution based on religion. It is this aspect that makes the social construction in the City of Bekasi different in any other cities: the characteristics of being urban and village areas altogether at the same time. Most of the immigrants from all areas throughout Indonesia who try to earn their fortunes in Jakarta live in the buffer cities like the City of Bekasi. As a result, their presence has contributed to the composition of population distribution based on ethnicity and religion in the City of Bekasi. The number of the population in the City of Bekasi based on religion and faith is provided in Table 1 below.

Table 1. Number of Population in the City of Bekasi Based on Religion and Faith 
28 | International Journal of Scientific and Management Research 04 (03) 09-25

\begin{tabular}{|c|c|c|c|c|c|c|c|c|}
\hline \multirow{2}{*}{ District } & \multicolumn{8}{|c|}{ Religion } \\
\hline & Islam & Christian & Catholic & Hindu & Buddha & Confucious & Faiths & Total \\
\hline Pondokgede & 240.687 & 20.867 & 6.759 & 1.590 & 976 & 25 & 530 & 271.434 \\
\hline Jatisampurna & 93.498 & 8.112 & 3.308 & 530 & 398 & 11 & 238 & 106.095 \\
\hline Pondok Melati & 130.675 & 12.387 & 6.904 & 1.460 & 701 & 19 & 49 & 152.195 \\
\hline Jatiasih & 186.994 & 15.645 & 4.614 & 1.460 & 982 & 24 & 175 & 209.894 \\
\hline Bantargebang & 93.596 & 2.689 & 791 & 424 & 323 & 11 & 96 & 97.930 \\
\hline Mustika Jaya & 125.976 & 11.772 & 3.197 & 635 & 630 & 11 & 75 & 142.296 \\
\hline East Bekasi & 233.295 & 21.199 & 7.945 & 7.134 & 6.317 & 14 & 47 & 275.951 \\
\hline Rawalumbu & 159.070 & 25.323 & 6.450 & 2.541 & 2.533 & 10 & 80 & 196.007 \\
\hline South Bekasi & 182.078 & 18.465 & 7.644 & 1.736 & 1.297 & 13 & 35 & 211.268 \\
\hline West Bekasi & 279.677 & 19.412 & 8.730 & 2.540 & 1.624 & 34 & 97 & 312.114 \\
\hline Medansatria & 141.349 & 15.327 & 7.470 & 3.879 & 3.219 & 15 & 62 & 171.321 \\
\hline North Bekasi & 274.512 & 24.787 & 7.958 & 4.023 & 3.492 & 14 & 102 & 314.888 \\
\hline Total & 2.141.407 & 195.985 & 71.770 & 27.952 & 22.492 & 201 & 1.586 & 2.461 .393 \\
\hline
\end{tabular}

Source: Kota Bekasi dalam Angka 2018 (BPS Kota Bekasi)

In relation to the above data, the religion distribution demands the establishment of prayer house. With regards to the statement, the development of housing complex in the City of Bekasi such as Bekasi Timur Regency, Pondok Pekayon Indah, Wisma Asry, Pondok Tmur Indah Kota Bekasi, and alike has been the fertile land for the development of Christianism and also for the establishment of Christian churches. As a result, the City of Bekasi Government should deal with quite serious problems in relation to the establishment of prayer houses, for example: (1) the construction of new prayer house along with the relevant permits; (2) the use of public facilities such as house, shop house, and field as part of prayer house; (3) the protest displayed by the surrounding communities toward the presence of the prayer house; and (4) the revocation of the church construction permit by the Mayor. Indeed, these churches have already had their permit but, due to the insistence from the groups of other religions, the government officials have eventually decided to revoke their permit. It is recorded that there have been 12 cases of prayer house permit revocation within the last few years (Jamaludin, 2018, p.228). In addition to these cases, Front of Anti-Apostasy Bekasi (FAPB, Front Anti-Pemurtadan Bekasi) used to ban the activities of Galilea Church (Gereja Galilea) in South Bekasi. In relation to the incident, Albi (Alliance of Islam in Bekasi or Aliansi Islam Bekasi), Forum of Moslem Communication in Indonesia (Forkami, Forum Komunikasi Muslim Indonesia), and Front of Islamic Defender (FPI, Front Pembela Islam) used to raid some churches and also ban their activities. One of the churches that have been targeted by these groups is the Church of Santa Clara.

Furthermore, sometimes the policy and the role of the government is considered to be taking side and discriminative. For example, the Mayor of Bekasi Regulation Number 68 of 2013 on 
the Implementation of Local Content Curriculum for History and Culture in Bekasi toward Elementary School Degree and Junior High School Degree has been considered as a discriminative policy. According to the National Commission of Human Right (Komnas HAM, Komisi Nasional Hak Asasi Manusia), the local content that has been formulated in this policy tends to feature both the majority religion and the majority ethnicity, whereas the City of Bekasi has diverse religions, faiths, and ethnicities. Consequently, this policy has the potential of not accommodating the other religions, faiths and ethnicities (Komna HAM, 2017, p.9).

Rahmat Effendi, the Mayor of Bekasi, once issued a prohibition policy for the activities of Ahmadiyah pilgrims through the Mayor of Bekasi Regulation Number 40 of 2013 dated October 23rd, 2011. Along with the issuance of the policy, the Indonesian Council of Ulama (MUI, Majelis Ulama Indonesia) also banned the activities of Friday prayer for the Ahmadiyah pilgrims in Al-Misbah Mosque, Bekasi. In addition, the City of Bekasi Government used to ban the Assembly of Indonesian Christian Church Taman Yasmin to perform their ministry on the pavement; in fact, their ministry used to dismiss by the Civil Service Police Unit in 2011 (Lampu Merah Kebebasan Beragama: Laporan Kebebasan Beragama dan Toleransi di Indonesia Tahun 2011, The Wahid Institute). On the top of it, there used to an incident of "praying dismisaal" in Cikarang, the Regency of Bekasi. Although the parties that had been involved in the incident have already been reconciled, still this incident has sparked a new problem. Therefore, looking at these cases, the City of Bekasi should guarantee that all people in the City of Bekasi can pursue the freedom in holding their prayers and ministries.

The heterogenous background of the society, the discriminative policy, and eventually the religious freedom have mingled together into an interrelated situation. Therefore, any form of resistance, prohibition, dismissal by the majority to the minority, and government involvement in such situation has been highlighted by many people. For example, in the resistance upon the construction of a church, some people from conservative Islam, the Forum of Harmony among the Religious People (FKUB, Forum Kerukunan Umat Beragama), and the City Government have been involved. On February 12th, 2015, the Mayor of Bekasi had banned three churches namely the Indonesian Graceful Church of Christ (GKRI, Gereja Kristus Rahmani Indonesia), the Batak Protestant Church (HKBP, Huria Kristen Batak Protestan) Kaliabang, and the Pentecost Church (Gereja Pantekosta). The Forum of Harmony among the Religious People (FKUB, Forum Kerukunan Umat Beragama), the City of Bekasi, also took role in the banning. During the closure of these churches, the Secretary of the Forum, Hasnul Khalid, stated that his office had taken records on 260 prayer houses that had been constructed without proper construction permit in Bekasi. Therefore, at that time he demanded that these 260 prayers houses to immediately propose the construction permit.

In another occasion, the hard-line Islamic groups demanded the local officials to close the mosque around Pondok Gede. Specifically, these groups demanded the closure of the only operating mosque for the Ahmadiyah pilgrims in the City of Bekasi. In order to do so, they urged the Mayor of Bekasi, Rahmat Effendi, to follow up the Joint Decree of AntiAhmadiyah Activities. Thus, the decision was eventually put in effect on October 13th, 2011. Within the closure, the Mayor of Bekasi stated that the Ahmadiyah pilgrims and their organization should stop all activities, including their da'wah, teaching dissemination, and any other ideas or activities that resembled Ahmadiyah (Human Right Watch, 2013).

With regards to the incident, Titik Sartika, Sadr Lajnah Imaillah Ahmadiyah in the City of Bekasi, the Province of West Java, shared about the intimidation that the Ahmadiyah Moslems had experienced in the City of Bekasi on November 2011 (http://www.hrw.org/id/report2013). She said: 
We are very afraid whenever we go to the mosque and this being afraid is highly perceived among the mothers and the children. As mothers, we are always afraid whenever we bring our children to the mosque. Actually, we used to have Sunday school but now we do that inside [in the house]. We are very afraid. The mothers are even unwilling to go the mosque whenever they meet the people with white robe [members of the Front of Islamic Defender].

The presence of intolerant act used to impact the ministries of Huria Kristen Batak Protestan (HKBP) Bekasi. Quoting from KBR.id, the Chief of Council of Churches in Indonesia (PGI, Persekutuan Gereja-Gereja di Indonesia) Gomar Gultom states that there should be strict actions taken by the police department in dealing with the perpetrators of intolerant acts who target churches. The state holds the authority to take decision upon the intolerant people. However, the state does not take such action and, therefore, such intolerant acts keep on lingering within the society and people keep being intolerant to the others (Rony Sitangga, 2020).

Transformation of the City of Bekasi: From the City of Intolerance into the City of Tolerance

The City of Bekasi has earned the sixth place in the Index of Tolerant City 2018 with the score 5.890. This city, a city which society is heterogenous but is able to mutually respect each other, has earned such a high score along with other 9 cities throughout Indonesia. The presence of the City of Bekasi Government in the middle of the society has resulted in the transformation of the city into the city of tolerance in Indonesia.

The concept of tolerance can be found in several systemic variables within the City of Bekasi. These systemic variables, which have influenced the inter-identity and inter-entity social behaviours among the population, consist of policies, actions, behaviours among the entities, behaviours among the people, behaviours between the City Government and the people, and the relationships within the demographic heterogeneity within the city. Halili (2018) explains that in the indexing study of Tolerant City there are several attributes that have been definitive namely: (1) the City Government has conducive regulations for the practice and the promotion of tolerance; (2) the statement and the action of the City Government apparatus are conducive for the practice and the promotion of tolerance; (3) the City displays the low to none extent of incidents that violate the freedom to embrace certain religion/faith; and (4) the City displays sufficient efforts in managing the diversity of religious identities within the society.

In accordance with the above finding, there are two Non-Governmental Organizations (NGOs) that used to perform the indexing toward the cities in Indonesia with regards to the issues of equality and multiculturalism namely SETARA Institute and MAARIF Institute. Both institutes has performed the indexing by conducting a research on the Index of Tolerant City (IKT, Indeks Kota Toleran). The first indexing effort took place in 2015. On the contrary, the MAARIF Institute performed the similar index under the name of Index of Islamic City (IKI, Indeks Kota Islami), which had been done in 2015-2016 for the first time. However, from both institutes, it is only SETARA Institute that consistently performs the indexing on the same cities. Departing from the consistency displayed by SETARA Institute, it is at least apparent that the cities have displayed the transformation from being an intolerant city to a tolerant city and vice versa.

Then, there are four variables that SETARA Institute has implemented. From the four variables, SETARA Institute has derived eight indicators. The first variable is related to Government Regulation and consists of two indicators namely: (1) Regional Mid-Term Development Plan (RPJMD, Rencana Pembangunan Daerah Jangka Menengah); and (2) Discriminative Regional Regulations. Next, the second variable is related to Government 
Action and consists of two indicators namely: (1) Government Statement; and (2) Government Response toward the Given Incident. Afterward, the third variable is related to Social Regulation and consists of two indicators, namely: (1) Incidents of Violation toward the Freedom of Embracing Religion or Faith; and (2) Dynamics of Civil Society. Last but not the least, the fourth variable is related to Religion Demography and consists of two indicators namely: (1) Religion Heterogeneity; and (2) Social Religion Inclusion.

The scores that have been released by the SETARA Institute with regards to the Top Ten of Tolerant City in Indonesia can be found in Table 2 below.

Table 2. The Complete Scores of the Top Ten of Tolerant City in Indonesia

\begin{tabular}{|c|c|c|c|c|c|c|c|c|c|}
\hline \multirow{2}{*}{ City } & \multicolumn{2}{|c|}{$\begin{array}{c}\text { Government } \\
\text { Regulation }\end{array}$} & \multicolumn{2}{|c|}{ Social Regulation } & \multicolumn{2}{|c|}{$\begin{array}{c}\text { Government } \\
\text { Action }\end{array}$} & \multicolumn{2}{|c|}{$\begin{array}{c}\text { Religion } \\
\text { Demography }\end{array}$} & \multirow{2}{*}{$\begin{array}{l}\text { Final } \\
\text { Score }\end{array}$} \\
\hline & Ind 1 & Ind 2 & Ind 3 & Ind 4 & Ind 5 & Ind 6 & Ind 7 & Ind 8 & \\
\hline Singkawang & 0.633 & 1.330 & 1.400 & 0.700 & 0.600 & 1.050 & 0.300 & 0.500 & 6.513 \\
\hline Salatiga & 0.517 & 1.260 & 1.400 & 0.700 & 0.600 & 1.050 & 0.250 & 0.700 & 6.477 \\
\hline Pematang Siantar & 0.400 & 1.330 & 1.400 & 0.700 & 0.600 & 1.050 & 0.300 & 0.500 & 6.280 \\
\hline Manado & 0.450 & 1.330 & 1.200 & 0.500 & 0.600 & 1.050 & 0.200 & 0.700 & 6.030 \\
\hline Ambon & 0.550 & 1.260 & 1.400 & 0.600 & 0.600 & 0.750 & 0.200 & 0.600 & 5.960 \\
\hline Bekasi & 0.450 & 0.990 & 1.200 & 0.600 & 0.700 & 1.050 & 0.300 & 0.600 & 5.890 \\
\hline Kupang & 0.517 & 1.190 & 1.400 & 0.500 & 0.500 & 0.900 & 0.250 & 0.500 & 5.857 \\
\hline Tomohon & 0.433 & 1.050 & 1.400 & 0.600 & 0.600 & 0.900 & 0.250 & 0.600 & 5.833 \\
\hline Binjai & 0.400 & 1.330 & 1.400 & 0.400 & 0.700 & 1.050 & 0.150 & 0.400 & 5.830 \\
\hline Surabaya & 0.433 & 1.190 & 1.200 & 0.600 & 0.700 & 0.900 & 0.300 & 0.500 & 5.823 \\
\hline
\end{tabular}

Source: Setara Institute, 2018

For SETARA Institute, the aim of indexing is to propose the issues of tolerance as the mainstream issue. Then, cities become the focus of the research due to the consideration on the heterogeneity. Indeed, the extent of heterogeneity in cities tend to be higher than that in regencies. Then, specifically, the City of Bekasi is selected because the City has fallen into the above categories and accidentally the trend of intolerance has been on the rise within the city. Halili, the Director of SETARA, explains:

So, we really performed a scientific and objective study. Indeed, we do not want to gain any feedback. However, the basis for the cities that we have surveyed or the cities that we have indexed is value in order to that the level of the tolerance there can be improved. Since the basis is value, certainly there will not be any feedback that we would like to expect from these cities other than the improvement on the level of tolerance among these cities. What is important to us is how the issues of tolerance can be a collective agenda for these cities so that the issues of tolerance can be turned into an institutional agenda and, thus, the conducive situation can be maintained and improved.

At the beginning, tolerance or intolerance is not a term that the City of Bekasi Government has paid attention to. Numerous policies and attitudes that the government and the society of Bekasi have shown are still dominated by the politics of identity initiatives, which tend to 
abandon the other identities or, worse, which tend to consider that other identities should be eliminated. Through the indexing of the most intolerant city, the City of Bekasi Government has found the baseline or the parameter for improving the tolerance under their government.

According to the terminology of Ernest Bormann, what SETARA Institute has done with the indexing can be identified as the construction of fantasy theme. The Institute has dramatized the theme tolerance into its perspective and thus has striven forward to turn the theme of tolerance into the common issue. Afterward, the Institute has started to evaluate and label the intolerant cities, in this case to the City of Bekasi, and eventually the Institute has publicly announced the results of the indexing. This situation has indirectly influenced the perspective of the elites within the City Government and even the political elites as well as even the society in the City of Bekasi as well. Since the aim of the indexing is to promote the cities that have been considered successful in establishing and developing the tolerance within their own regions, the other cities will certainly be triggered to pursue such establishment and development of tolerance within their own regions as well (https://setara-institute.org/indekskota-toleran/). With regards to the statement, Halili states:

In SETARA, we talk about equality. The mandator of our organization is how we can create equal society and this includes society of both majority and society since, in factual terms, the relationship between majority and minority has been less beneficial for the minority. There has been an inequal relationship between majority and minority. Minority tends to the victim, while majority tends to be the perpetrator in several incidents of tolerance violation. Therefore, the values of equality that we have been fighting for is not about how to make the City of Bekasi supports what we have been doing since we don't expect any feedback from the cities that we have scored.

The reaction displayed by the Government and the society of the City of Bekasi has marked that the Fantasy Chain has been created. In 2016, both the government and the society of Bekasi started to respond to the stigma of being an intolerant city. Thus, the City of Bekasi Government started to review the Mayor of Bekasi Regulation Number 68 of 2013 on the Implementation of Local Content Curriculum for History and Culture in Bekasi toward Elementary School Degree and Junior High School Degree (Komnas HAM, 2017, pp.19-20). This reaction has shown that the symbolic convergence and the basis of common meaning unification with regards to equality have been created. The Mayor of Bekasi altogether with the Forum of Harmony among the Religious People (FKUB, Forum Kerukunan Umat Beragama) established the Assembly of Religious People (MUB, Majelis Umat Beragama) within the same year. The establishment of the MUB has been to internalize the values of tolerance and equality in the district level. The Mayor of Bekasi, Rahmat Effendi, states that, "There is not any majority nor minority, there is not any religious discrimination, there is not racial discrimination, there is not any tribal discrimination, and there is not even any cultural discrimination because all of us are the residents of the City of Bekasi" (https://www.poskotanews.com/2016/11/14).

At the third stage of convergence, Fantasy Type, the themes of tolerance and intolerance are socialized recurrently to the society. In this stage, these themes have been discussed on another situation with different actors and different backgrounds; however, the plot of the narrative is still the same. In 2017, the Mayor of Bekasi altogether with the Assembly of Religious People declared the spirit of diversity known as kebhinekaan. The member of the Forum of Harmony among the Religious People, who represented Parisada Hindu, stated that:

We have taken initiatives in socializing this spirit of diversity. First of all, we held the declaration of religious people in the soccer stadium and the declaration was attended by the religious figures and the public figures throughout the City of Bekasi. The total number of the participants was around 10,000 people back then in 2017. Then, we 
also held another declaration on the district level. We invited 12 district heads in order to persuade the religious figures and the public figures to attend the similar declaration in the soccer stadium."

The role of the Mayor has been very significant for the society in making the society aware that the issues of tolerance and intolerance have been part of the shared themes. With regards to the statement, the Secretary of the Body of Nation and Politics Unity (Sekretaris KESBANGPOL) the City of Bekasi, Aan, states:

As we have well understood, Mr. Pepen has been trying his best to embrace the society in order to be tolerant and appreciating the differences. The reason is that the City of Bekasi is a heterogeneous city. In other words, it can be understood that the City of Bekasi has been the miniature of the Republic of Indonesia since in this city we can find people from various background of ethnicities, characteristics, and religions. That's the reason why our Mayor and Vice Mayor have been working hard to develop the sense of communalities and diversity within the society, especially in terms of procuring the prayer facilities. Therefore, the City of Bekasi Government has provided directions on the appreciation toward the mutual respect from one religion to another. At the same time, the City Government should pay attention to the praying facilities for all regions. For example, we have provided a praying place for our Hindu relatives in Rawa Lumbu.

In 2017, several problems that had been related to the policies started to be settled. For example, the policy on the Implementation of Local Content Curriculum for History and Culture in Bekasi toward Elementary School Degree and Junior High School Degree was deprived. At the same time, the conflicts on the construction of four churches started to be solved. The Mayor of Bekasi determined to issue the construction permit, which used to be resisted by the Islamic mass organizations. Thus, the construction permit for the four churches, namely the Church of Santa Clara, the Church of Galilea, the Church of Kalamiring, and the Church of Manseng, was issued. Not only that, the City of the Bekasi had not only issued the construction permit (IMB, Ijin Mendirikan Bangunan) but had also been committed to defend the construction permit since the permission process that the four churches had gone through was already in accordance with the governing legal requirements (Komnas HAM, 2017, pp.15-16).

The development that has been pursued by the City of Bekasi starts to show positive signs. According to a research by SETARA, namely the Index of Tolerant City 2017, the score for the City of Bekasi has improved form the two-bottom or 93 out of 94 cities in 2015 into 53 out of 94 cities in 2017. Thus, the City of Bekasi has leaped from Cluster 4 to Cluster 3. Such significant progress has been mainly supported by the increasing positive standing position, statement, and action made by the Mayor of Bekasi, Rahmat Effendi, in responding to the incidents of intolerance. Recently, the Mayor of Bekasi Rahmat Effendi was protested by the mass from the intolerant organizations and the protest ended in a commotion between the intolerant organizations and the security apparatus in charge. These intolerant groups demanded that the Mayor should deprive the construction permit for the Church of Santa Clara but he delivered a very strong message of tolerance, namely that he would not deprive the construction permit for the Church of Santa Clara only because of being protested or intimidated by a group of people or even the mass (https://setara-institute.org/indeks-kotatoleran-tahun-2017).

At the final stage, Rhetorical Vision, the fantasy themes that have developed and expanded outside the context of the group that has developed the fantasy themes. The preliminary fantasy themes that have been developed will eventually turn into the rhetorical visions. Then, these fantasy themes will develop into the communal or the mass-wide fantasy themes 
and eventually shape the rhetorical community. In each analysis of fantasy themes or rhetorical themes on the wider level, there are always four main elements namely: (1) the figures in involvement (dramatic personae or characters); (2) plot lines; (3) scenes; and (4) sanctioning agents.

SETARA Institute has successfully created the rhetorical vision on the tolerance in the City of Bekasi. This theme has been a matter of discussion among many people. According to the Forum of Harmony among the Religious People in the City of Bekasi, in 2018 the Assembly of Religious People in each village has declared the spirit of diversity or known as kebhinnekaan. The statement has been supported by one of the officials in the Body of Nation and Politics Unity, who states that:

In 2018, we have completed the socialization in the village level. So, we have invited 12 districts and 56 villages within the socialization. In 2019, we have also completed the socialization to the senior and vocational high school degree. In the meantime, the socialization has still been on progress for the Citizens Association (RW, Rukun Warga). We have tried our best to get to the root of the society and this means that we are working to equip the society with the ways to maintain the harmony among the religious people and also the ways to ask for the construction permit of the prayer house so that conflicts can be avoided in the future.

Such transformation is also perceived by the society and the government of the City of Bekasi. Indeed, this act is a positive initiative that should be developed together in order to achieve the slogan of the City with the Spirit of Bhinneka Tunggal Ika. The reason is that there has been diversity in terms of ethnics and religions within the City of Bekasi. Therefore, the City of Bekasi should be a role model of tolerance due to the heterogeneous society. In addition, along with the transformation, the City of Bekasi should take the preliminary step, altogether with the society and the relevant stakeholders, in contributing to the progress toward the higher sense of tolerance. In order to do so, the society in the City of Bekasi should have good prejudice toward others so that they will able to take the good steps. In addition, the society should also establish good communication since every single problem can be solved well through good communication since tolerance will be tested by how far the society is willing to turn back the hoax. Therefore, the society should be proactive in battling the hoax in order to preserve and improve the sense of tolerance (Bekasi.id, 2018). Furthermore, one of the important ways for establishing good communication is showing care to each other. If people help each other and care with one another, then the tolerance will always be well-preserved (Bekasi.id, 2018).

The transformation that the City of Bekasi has undergone cannot be separated from the role of the Moslem clerics and the religious figures, who are able to work hand in hand in order to develop a peaceful city and to establish good communication. As a result, the vision and the mission of the City of Bekasi, namely being a City of Intelligence, Creativity, Advancement, Prosperity, and Nobility, can be achieved. In order to maintain this situation, the City of Bekasi should provide the sense of security, comfort, and common understanding along with the equal and well-assured rights of accessing education and health service. The solid proof of the latter statement is the distribution of the Health Card that has been distributed to the residents in the City of Bekasi.

Such positive transformation has delivered the City of Bekasi into the position of a role model for the other cities. In 2018, the Index of Tolerant City by SETARA Institute has provided the enormous score for the City. The City of Bekasi has occupied the top six of Tolerant City out of 94 cities under assessment (https://setara-institute.org/indeks-kotatoleran-ikt-tahun-2018/). The consistency displayed by the City of Bekasi Government in dealing with the issues of tolerance has been appreciated by many parties. In the event of 
Indonesia Award 2019, the City of Bekasi has won the nomination of the City of Harmony (Kota Harmoni) 2019. Thus, it can be concluded that the City of Bekasi has successfully managed the multicultural society so that the members of this society are empowered to appreciate differences.

\subsection{CONCLUSIONS}

The City of Bekasi has made a wonderful achievement in terms of harmony and diversity through a very long way of transformation. Behind all odds that the City might have, SETARA Institute has played a significant role in influencing the political elites, the government, and the society within the City of Bekasi through its symbolic convergence. In this initiative, the values of equality are reviewed and advocated to the cities throughout Indonesia through the Index of Tolerant City (IKT, Indeks Kota Toleran) that has been consistently performed from 2015 until 2018. The beneficiaries, especially the relevant parties and authorities, of the index results do not only read the index but also evaluate the index. One of the examples can be found in the figure of Rahmat Effendi, who has become the central figure behind the transformation in the City of Bekasi. The awareness toward the importance of pursuing tolerance in his region becomes the basis of the shared evaluation. Gradually, the Mayor of Bekasi disseminates the values of equality to the root cause, namely the Citizen Association, and to the young generation, namely the students in the school degree.

\section{LIST OF REFERENCES}

\section{Books and Journals}

Bormann, Ernest G. 1985. "Symbolic Convergence Theory: A Communication Formulation". Journal of Communication, Vol. 35, Tahun 1985.

Bruinessen, Martin van. 2013. Contemporary Developments in Indonesian Islam: Explaining the "Conservative Turn". Singapore: ISEAS Publishing.

Burhani, Najib. 2017. “Indonesia Pasca Aksi Bela Islam”, Jurnal MAARIF, Edisi Desember 2017.

Cooley, C. H. 1902. Human Nature and the Social Order. New York: Scribner's Sons.

Djojosuroto, KInayanti. 2011. "Dialek dan Identitas Jawa Tondano di Mianhasa: Suatu kajian Historis”. Jurnal Didaktika Dwija Indria Vol 1, No 1 Tahun 2011

Halili, dkk. 2013. Kepemimpinan Tanpa Prakarsa, Kondisi Kebebasan Beragama/Berkeyakinan di Indonesia 2012, Jakarta: Pusatka Masyarakat Setara.

Halili, dkk, 2018, INDEKS KOTA TOLERAN (IKT) TAHUN 2018, SETARA Institute for Democracy and Peace.

Hayat, Bahrul. 2012. Mengelola Kemajemukan Umat Beragama. Jakarta; PT. Saadah Cipta Mandiri.

Jamaludin, Adon Nasrullah. 2018. "Konflik Rumah Ibadah di Kota Bekasi”, Jurnal SocioPolitica, Vol. 8, Nomor 2 Edisi Juli 2018.

Lippman, Walter. 2007. Public Opinion. US: Filiquarian Publishing. E-Book.

Morisan, Mass Communication Theory, (Bogor: Ghalia Indonesia, 2010). 
Noorbani Agus M, 2019, Kerukunan Umat Beragama Di Kampung Sawah kecamatan Pondok Melati Kota Bekasi, Jurnal “Al-Qalam” Volume 25 Nomor 2, Desember 2019.

Rosyadi et al. 2010. Peta Budaya Kabupaten Bekasi, Departemen Kebudayaan dan Pariwisata. Bandung: Balai Pelestarian Sejarah dan Nilai Tradisional.

Sopandi, Andi. 2006. "Identifikasi Pola dan Strategi Peningkatan Integrasi Masyarakat di Kota Bekasi”, Jurnal Madani, Edisi II November 2006.

Sopandi. 2009. Sejarah dan Budaya Kota Bekasi, sebuah Catatan Perkembangan Sejarah dan Budaya Masyarakat Bekasi. Bekasi: Dinas Pemuda Olahraga, Kebudayaan, dan Kepariwisataan.

Suparman, Nana. 1985. Mengenal Bekasi Kota Patriot. Bekasi: Rahman Press.

Suryadi, Israwati. 2010. "Teori Konvergensi Simbolik", JURNAL ACADEMICA Fisip Untad. Vol. 2 No. 02 Oktober 2010

Sutanto, T. 2007. "Melampaui toleransi?: Merenung bersama Walzer" dalam Ihsan Ali-Fauzi, dkk. Demi Toleransi Demi Pluralisme. Jakarta: Paramadina.

Subiakto Utamie Vania, Political Advertising On Mass Media Construction, International Journal of Scientific and Research Publications, Volume 9, Issue 12, December 2019, ISSN 2250-3153.

Syahra, Rusydi. 2003. Modal Sosial; Konsep dan Aplikasi. Jurnal Masyarakat dan Budaya. Volume 5 No. 1 Tahun 2003.

Tideman, J. 1983. Tanah dan Penduduk Indonesia, Penduduk Kabupaten Batavia, Meester Cornelis, dan Buitenzorg. Terjemahan Hasan Basri. Jakarta: Bhratara.

Varshney, Ashutosh. 2009. Konflik Etnis dan Peran Masyarakat Sipil; Pengalaman India(terj. Siti Aisyah, Ayu Diasti, \& Sri Murniati). Jakarta; Balai Litbang Agama Jakarta.

Wahid Foundation. 2016. Laporan Tahuan Kebebasan Beragama Berkeyakinan (KBB) di Indonesia tahun 2016 (Ringkasan Eksekutif). Jakarta; Wahid Foundation.

Zuhri, Saefudin. 2017. Deradikalisasi Terorisme: Perlawanan Muhammadiyah dan Loyalitas Nahdlatu Ulama. Jakarta: Daulat Press.

\section{Documents}

Human Right Watch, Atas Nama Agama Pelanggaran terhadap Minoritas Agama di Indonesia, accessed from https://www.hrw.org/id/report/2013/02/28/256413 on December 12th, 2019.

Kota Bekasi dalam Angka 2018 (BPS Kota Bekasi).

Lampu Merah Kebebasan Beragama: Laporan Kebebasan Beragama dan Toleransi di Indonesia Tahun 2011, Jakarta: The Wahid Institute.

Ringkasan Eksekutif Penelitian Pelaksanaan Kewajiban Pemerintah Daerah dalam Perlindungan Hak Atas Kebebasan Beragama dan Berkeyakinan di Jawa Barat dan Aceh Singkil. Komisi Nasional Hak Asasi Manusia Republik Indonesia 2017. 
Ringkasan Laporan, Indeks Kota Toleran 2015, SETARA Institute, Jakarta: 2015.

Ringkasan Laporan, Indeks Kota Toleran 2017, SETARA Institute, Jakarta: 2017.

Ringkasan Laporan, Indeks Kota Toleran 2018, SETARA Institute, Jakarta: 2018.

\section{Websites}

Asep 2016, Program Studi Agama dan Lintas Budaya Center for Relagions and Cross Cultural Studies Graduate School, Universitas Gadjah Mada diakses di https://crcs.ugm.ac.id/tag/intoleransi/

Bekasi.go.id, 2018, Kota Bekasi Raih Predikat ke 6 Kota Toleran di Indonesia diakses di https://www.bekasikota.go.id/detail/kota-bekasi-raih-predikat-ke-6-kota-toleran-diindonesia

Bekasi.go.id, 2018, Silaturahmi Tokoh Lintas Agama, Wali Kota Ucap Syukur Atas Toleransi di Kota Bekasi, diakses di https://www.bekasikota.go.id/detail/silaturahmitokoh-lintas-agama-wali-kota-ucap-syukur-atas-toleransi-di-kota-bekasi.

Erdianto Kristian, 2017, Perda Diskriminatif Dinilai Menjadi Penyebab Intoleransi Struktural diaksesdihttps://nasional.kompas.com/read/2017/03/16/16220211/perda.diskriminatif. dinilai.menjadi.penyebab.intoleransi.struktural.

KBR.id, 2020, Persekusi Ibadah di Bekasi, PGI Desak Pelaku Ditindak, diakses di https://kbr.id/nasional/092020/persekusi_ibadah_di_bekasi_pgi_desak_pelaku_ditind ak/103545.htmll 